\title{
On the Cultural Clash and the College English Teaching
}

\author{
Zhen Zhou \\ Foreign Languages College, Nanchang Normal University, Nanchang, Jiangxi, 330032 \\ zoye100@sina.com
}

Keywords: Cultural clash; Cross-cultural communication; Values; English teaching; Communicative competence

\begin{abstract}
The cultural clash is a common phenomenon in the cross-cultural communication since at present we have more chances to get in touch with the outside world more conveniently and frequently. And it is indispensable for us to try to avoid the cultural clash of the west countries and our China. The article firstly explains the phenomena of the ordinary cultural clash, then analyzes the underlying reasons for the cultural clash, and lastly puts forward some counter measures, that is, the teacher should change their teaching concepts, guide students to get in wide touch with the western cultures. Thus, the college English teachers should not only focus on imparting necessary language knowledge and skills, but also pay more attention to cultivating students' social linguistic ability and cross-cultural communicative ability. The article aims to supply some teaching reference for the college English teaching to improve students' cross-cultural communicative ability and ultimately enhance the college English teaching quality.
\end{abstract}

\section{Introduction}

After the opening-up and reform of China, more and more western things come to our life. And in such a case, cross-cultural communication becomes more and more, which provides us with many channels to get in touch with the western culture, and is also helpful for us to deepen our understanding of the western societies. However, when we Chinese people associate with foreign people who come from different countries, and have different cultures, values, thinking styles and different customs, cultural clash often occurs. Therefore, it becomes necessary to find the deep reason, and then try to cultivate college students' cross-cultural communicative ability and try to avoid the happening of cultural clash.

\section{The Ordinary Cultural Clash in the Cross-cultural Communication}

There are various cultural clashes in the cross-cultural communication and such frequent kinds are as follows:

The Clash of Time. The western people mostly believe that time is money, which is a deep-rooted concept. So the western people cherish time very much and they are good at planning their time and form the habit of being punctual. In the west, if you want to visit someone, you must notify or make an appointment in advance and explain the purpose, time and place of visiting. But Chinese people are very casual and flexible in their use of time. And Chinese people are often 5 to 10 minutes late for a party or feast or appointment, while western people arrive often 5 to 10 minutes ahead of time. Hence, western people feel unaccustomed to Chinese people's time concept, and it is the same case with Chinese people.

The Clash of Greeting. Chinese people often ask, "Have you eaten yet?" to greet each other, while western people often say something about the weather, like, 'It's raining today, isn't it?" to greet each other, or just say, "Hello!" to each other shortly and simply. Chinese people also show their concern and care for their friend, for example, "You look bad. Are you sick?" "Long time, no see. You are fatter." "You look so tired. Are you stressed out?" These greetings are very familiar and sound comfortable and close to our Chinese. But western people feel embarrassed even with close friends if they comment on their body shape or health condition. They most probably feel the friend is so rude and abrupt. 
The Clash of Praising. Chinese people think highly of being modest and humble. They believe that being modest is a virtue. When other people praise us, even if we are happy in our heart, we had better be modest to hide our pleasure. For example, once in a ball, an American praised a Chinese lady saying, "You look so beautiful today!" And the lady said, "Where, where!" The American knew some Chinese culture, so he said smartly, "Everywhere". But according to the western culture, when people are praised, they should accept happily and say "Thank you!" to accept the praise directly. Because of the differences of Chinese and western cultures, we think that western people are too confident and not modest at all. So when western people hear Chinese people deny their or others' praise, they feel so surprised that they think that Chinese are not honest, which is actually a misunderstanding.

The Clash of Table Manners. Chinese people are very hospitable and like to toast to each other in the feast. The master sometimes uses his chopsticks to pick up dishes for guests to enjoy and try their best to persuade guests to eat more dishes and drink more wine. But in the western countries, they respect people's rights and privacy; they do not force anything upon others so enthusiastically. When eating, western people do not pick up dishes for the guests out of their good will, and they respect the guest's likes and dislikes and they do not try their best to persuade guests to drink. The table manners are quite different.

The Clash of on the Meaning of Colors. As for color words, there are many differences which also often lead to cultural clash, Take "green" for example, although in Chinese, "green" has positive meanings, like "green revolution", "green food" which means biological and environmentally friendly food. Yet it also means a wife's extra-marriage relationship which brings shame to the husband, as in "green hat". But in English, "green" often means happiness, hope, youth, and vitality, which often means the returning of human's simple and pure spirit. "Green" also often refers to energetic life or being young and inexperienced as in the expression "green hand". But "green-eyed" is very confusing to Chinese, which means being jealous of someone else, but Chinese often use "red" to describe our eyes in such a case.

The Clash in Other Etiquette Aspect. Chinese people do not use the expression "Thank you!" as often as western people. Most often, only when other people offer a great help, we say "Thank you." to show our gratitude. As for western people, no matter between family members, or between superior and subordinate, or between seniors and juniors, they just often say "Thank you." just for a very small thing or something the others should do. This is their habitual answer, which does not mean that they are grateful. So if western people say "Thank you." to Chinese, we had better say, "It's my pleasure." or "You are welcome.", or "Don't mention it." If Chinese people say, "That's my duty.", and this will sound a little bit unpleasant, which clashes with the western culture.

\section{The Reasons for the Cultural Clash between the Chinese and Western Culture}

The Differences of the World View and Values. People's communicative ability can not live without our society, and it is closely related with values. In the cross-cultural communication, we can not avoid our world view and values which is deeply rooted in the culture. People just deepen their understanding on intercultural communication through knowing the differences of the world view and values, since many cross-cultural communicative problems arise from the contradiction of different world view and values.

The World View refers to People's Core View about the Whole World. The east and west hold different view about the relationship between people and Mother Nature. Chinese culture thinks that people should control nature and conquer it and people can use technology to reform nature, defeat it and humans are the center of the world. While the western culture asserts that humans and nature should be harmonious, and humans are closely related to nature, humans do not reform nature and they should adapt to nature and make use of natural condition to serve people. Values mean the criteria to judge whether what is good or bad, which can guide our behavior. Therefore, values are the basis of culture and social structure. But the judging measure of every culture is different. Maybe some acts are reasonable in one culture, but unaccepted or taboo in another culture. So we can not simply conclude that one value criterion is advanced and the other is backward. In the Chinese culture, we advocate the 
virtues of modesty, compromise, resilience and tolerance. And the society does not favor the people who are too outstanding and like showing off. In the Chinese culture, collective interests are above individual interests. While western culture upholds the spirit of "individualism", and "Being content with what we have." is considered to lack aggressive spirit and be lazy to the western culture. The western culture thinks highly of independent thinking, critical thinking and realizing personal interests through their own ability and exertion. Besides, Chinese care much about our face and we are modest. While western people care much about trying hard no matter they lose face or not.

The Differences of Connotation of Words. It's well-known that language is the carrier of culture. Different cultures have differences and the differences will be reflected in the language and become lingual differences. Language is the cultural production and is a form of culture. Hence, the use of language must abide by cultural principles. Different cultures have different using rules, and the norms of one culture can only be explained in some specific condition by the culture itself and it can not be used to describe another culture. Otherwise, it will inevitably lead to the failure of intercultural communication. The core reason is that people lack the sensibility to the social language differences and they often do some pragmatic transfer unconsciously and this will cause some problems, or even serious consequences. For example, a Chinese battery brand named "Baixiang" is translated into "White elephant", which led to a sale failure. The reason is that in western culture, "White elephant" means something useless. So the error of translation arisen from not understanding of the differences of the word cultural connotation.

The Differences of Non-verbal Behavior. Non-verbal behavior, just like verbal behavior, is often endowed with different meanings in different cultures. In the inter-cultural communication, because different cultures have different explanations of non-verbal language, misunderstanding often occurs. Non-verbal behavior is very similar to body language, but it is much wider-covering. Non-verbal behavior includes a lot of aspects, for example, people's garment, speaking voice, the layout of a room, spatial concept and so on. Some researches indicate that in people's communication, non-verbal behavior occupies $65 \%$, which means that non-verbal behavior is of great importance to people's communication. When people from different countries communicate with each other, they tend to use their own social norms to judge the others' behavior. And since the norms of the two parties are so different, misunderstanding and even worse consequences will occur. For example, in China, patting a child's head means care and love, but in the west, the act is considered to be rude and offensive, and the parents will be very angry. In order to guarantee the smooth going of intercultural communication, we must understand different non-verbal behavior; especially know more about the taboo in other culture. The best way is to do like Romans when you are in Rome.

\section{The Strategies to Cultivate Students' Cross-cultural Communicative Ability}

What is our core purpose of English teaching? Is it to study and research English or master the tool of the English language for most students? Definitely, to most Chinese students, the practical reason to learn English is to master the tool to communicate with the world. It is well-known that language has strong social communicative function and it is a tool for communication. When students learn a foreign language, they not only should have good abilities of comprehensive language using, but also should have strong cross-cultural communicative competence. Hedge discusses five main comments of communicative competence, that is, linguistic competence, pragmatic competence, discourse competence, strategic competence and fluency. Therefore teachers should try to improve students' cross-cultural communicative ability in the college English teaching through these five aspects.

The Teacher Changing Their Concepts. At present, in the college English teaching, teachers dominate the whole class and still emphasize too much the usage of grammar and vocabulary, and they often neglect students' pragmatic ability. So students can not easily acquire intercultural communicative ability in class effectively. Hence, the teacher should change their teaching concept, arm themselves with solid English pragmatic knowledge and then realize the importance of cultivating students' cross-cultural communicative ability. 
The Teacher Improving Their Teaching Methods. Constructivist education theory believes that teachers are not merely knowledge transmitter, and they should also help students construct their own knowledge system. For much a long time, the college English teaching attaches too much information on the teaching of language knowledge, neglecting to create situations for students to cultivate their cross-cultural communicative ability. In order to change this situation, teachers should improve their teaching methods and make full use of modern teaching methods, like mult-media, and internet to activate students' learning initiatives and help students construct their own knowledge system. When teachers improve their teaching methods, they should try to combine the knowledge and practical language use.

Guiding Students to Get in Wide Touch with the Western Culture. In the college teaching, the class time is very limited, but students have ample spare time. Hence, teacher can not cultivate students' cross-cultural communicative ability only in class and they should guide students to make full use of after-class time to read western literature works, newspapers, magazines, current affair comment, and learn culture knowledge, foster their cultural awareness and improve their cross-cultural communicative ability.

\section{Conclusion}

As the high technology develops and the world becomes a global village, we get in touch with other countries much more conveniently and frequently. It is of great importance to avoid the cultural clash of the west countries and our China. As for the college English teaching, the teacher should not only attach importance to imparting necessary language knowledge and skills, but also pay more attention to fostering students' social linguistic ability and cross-cultural communicative ability, which is a very demanding task for college English teachers.

\section{Acknowledgements}

This work was supported by the school project of Nanchang Normal University, named "The research into college students' English learning belief and learning strategy." (15RWYB21).

\section{References}

[1] Birdwhisted Ray, 1970, Kinesics and Context, Philadelphia: Pennsylvania University Press.

[2] Guojin Hou. The essence of pragmatics: pragmatics versus pragmatic mistakes. Beijing: World Book Publishing House. 2014.

[3] Hall, Joan Kelly. Teaching and researching language and culture[M]. Beijing: Foreign language teaching and research press, 2005.

[4] Huaikui LI. The research into 12 pragmatic ablity: theory and practice. Shanghai: Shanghai Jiao Tong University Publishing House. 2013.

[5] Jiawei Lu. The effect of classroom instruction on the development of learners' pragmatic competence in the cognitive framework. Journal of PLA Foreign Languages Institute, 2013, (1):67.

[6] Kramsch, Claire. Language and culture [M]. Shanghai: Shanghai Foreign Language Education Press, 2000.

[7] Teng Ma. The interlingual pragmatic ability of English majors and the training mode. Beijing: China science Publishing House. 2013.

[8] Williams, M. \& Burden, R.L., Students' developing conceptions of themselves as Language Learners, J. The Modern Language. 1997(83): 193-201. 
[9] Xiaoxi Sun. Development on L2 pragmatic competence. Shanghai: Shanghai Jiao Tong University Publishing House. 2009.

[10]Zhanhao Jiang. The research into pragmatic ability in the view of intermediary language pragmatics. Beijing: Beijing University Publishing House. 2013. 